\title{
AN EVALUATION OF WIL TRAINING FOR DURBAN UNIVERSITY OF TECHNOLOGY CIVIL ENGINEERING - EMPLOYER AND STUDENT EXPERIENCE: LESSONS FOR THE NEW PROGRAMME
}

\author{
B. P. Khuzwayo* \\ https://orcid.org/0000-0003-3967-7126
}

\section{S. Vahed*}

https://orcid.org/0000-0003-2865-9416

*Department of Civil Engineering and Geomatics

Durban University of Technology

Durban, South Africa

\section{ABSTRACT}

The Durban University of Technology (DUT) previously offered the now phased-out National Diploma in Civil Engineering, incorporating a two-year academic enrolment and a year-long workintegrated learning programme (WIL). The support offered by the University lecturers was essential in the WIL, to ensure that the engineering tasks assigned to students aligned with the DUT curriculum; any concerns or comments expressed were investigated further and addressed appropriately. In 2017 and 2018 interviews were conducted, generating 918 structured comments by employers. These included 304 general comments (with no academic value) and 593 comments specific to disciplines by students, of which 346 were general comments. This exploratory study aims to determine critical feedback that should be considered when enrolling for the new qualification: Bachelor of Engineering Technology Degree in Civil Engineering (B Eng Tech degree). The data received helped to discover and understand the experiences, perspectives and thoughts of the participants who responded to open-ended questions (i.e., comments about their experiences, without any limitations).

The data collected were presented and evaluated using the thematic analysis method to discover patterns and to develop subjects for discussion. Findings show that employers were generally happy with the quality of the students from DUT, however, they found professionalism among the DUT students to be a major concern. They also requested that the institution communicates with employers regarding the curriculum so that employers might properly align the WIL with it. Most students were challenged by the new work environment they had entered. The most common factor that made the experience more challenging was the exposure to the stateof-the-art equipment used in the workplace.

Keywords: National Diploma in Civil Engineering, Work Integrated Learning, Bachelor of Engineering Technology Degree in Civil Engineering 


\section{INTRODUCTION AND BACKGROUND}

The 3-year National Diploma in Civil Engineering (NDCE) has a 1-year Work Integrated Learning (WIL) component. This qualification is currently being phased out at the Durban University of Technology (DUT) in favour of the Bachelor of Engineering Technology Degree in Civil Engineering (B Eng Tech degree). Several studies (Winberg et al. 2011; Cooper, Orrell, and Bowden 2010; Smith, Ferns, and Russell 2014; Oliver 2015; Jackson 2015) have documented the benefits of WIL namely:

- Academic benefits, such as improved general academic efficiency, improved interdisciplinary thinking, increased enthusiasm for learning;

- Personal benefits include improved communication skills, teamwork and co-operation;

- $\quad$ Career benefits such as career clarification, professional identity, increased employment opportunities and salaries, the development of positive work values and ethics; and

- Development of skills including increased skills and increased technical knowledge and competencies.

Within the context of the Engineering profession (Nair 2020; Blom and Saeki 2011; Majumdar 2017; De Stavenga Jong, Wierstra, and Hermanussen 2006), the key aspects influencing employability of engineering graduate students included but were not limited to:

- $\quad$ Engineering Knowledge;

- Problem Analysis; Design/development of solutions;

- Conduct investigations of complex Problems; Modern tool usage; Individual and team work; and

- Communication.

The article revisits the records of structured interviews for the phased out National Diploma in Civil Engineering (NDCE) Work Integrated Learning (WIL) section - employer and student experience. The aim of the study was to synthesise a large quantity of unorganised data and information and to reformat this in a way that is accessible and useful. The objective is to present the data chronologically and in a way that readers can easily digest. The data can then be used to:

(1) inform the development of the new qualification: Bachelor of Engineering Technology 
Degree in Civil Engineering (B Eng Tech degree); and

(2) inform or share the outcomes with the public and the world of academia about the employer and student experience at the Durban University of Technology (DUT).

If the outcomes of the study are considered, they could help the Durban University of Technology to produce B Eng Tech degree graduates of the calibre that should perform better in the industry with respect to the aspects laid out at the conclusion of this study despite the exclusion of WIL in the enrolled programme.

Collaboration between the University and employer is vital to ensure the credibility and status of the qualification. Lecturers, mentors and/or supervisors (from the University) provide support through assessment criteria to ensure that the engineering tasks assigned to students are in alignment with the DUT curriculum. The role-players within WIL include:

- $\quad$ The learner (student).

- The Durban University of Technology Co-operative Education - tasked to assist learners getting recruitment.

- The Durban University of Technology Department WIL Coordinator who allocates lecturers as WIL supervisors.

- The Advisory Board - tasked with linking industry to the curriculum, thereby linking theory to practice.

- The employer and the mentor (who is registered with the Engineering Council of South Africa, (ECSA).

The experiential learning of students is administered and controlled by the University. However, the evaluation of experiential learning done by a student is primarily the responsibility of the employer involved. The validating of every aspect of experiential learning concerning its suitability and acceptability for the granting of the NDCE, including the administration of experiential learning is primarily the task of the University. Every student who undertakes experiential learning must undergo an interview with the Experiential Learning Co-Ordinator/s at their place of work. A logbook is issued to document the experience obtained at the workplace. The experience refers to the work done by the student with respect to a specific aspect during the learning period. The recording is certified by the workplace mentor (i.e., immediate supervisor), who should be the training supervisor registered with ECSA. A student may be employed at the end of the first year without completing the necessary subjects that 
could be required by the employer. Although this situation is not ideal from an educational perspective, the need and availability for training outweighs this. WIL should be undertaken and should be conducted within the confines of the structure stipulated in the students' logbook that includes the core areas that the student may explore. WIL should provide a student with exposure to each of the specialist areas listed below:

- Administration: report writing, planning and programming, plant management, etc.

- Drawing: structural steel and concrete drawings, sewerage and stormwater drawings, topographical map work, etc.

- Surveying: types of surveys (for example: traverse), levelling, survey instruments (for example: Theodolite).

- Design: roads (for example: earthworks), structures (for example: retaining wall/s), water (for example: flood routing), etc.

- Contract administration: schedule of quantities, estimating, and contract certificates, etc.

- Construction supervision: marine works, quarrying and rail maintenance, etc.

- Material testing: such as soil, asphalt and chemical.

The list of exposure incorporates the type of work that is common in the Civil Engineering industry where students could begin to earn their experience. It was developed sometime back, based on the theory work covered in the phased-out: NDCE. Once a lecturer is allocated to a student, they need to conduct an interview with the employer in order to receive feedback about his/her experience with the university student. The employer is a vital component of the quality assurance, being responsible for ensuring that the student has completed his/her experiential learning satisfactorily. The employer evaluates the student with reference to a specific experiential learning task. The experiential learning programme offered by an employer should be structured in accordance to their own specific needs, specialisation field, situation, structures and procedures for the National Diploma. The interviews and a logbook provide essential feedback to the University, pointing out the direction to the areas of improvement. These include (but are not limited to) curriculum student development, etc. The feedback enables the University to attend to the areas of concern and put in place mechanisms to improve their performance during the theoretical training and prepare them better for the experiential learning period. This exploratory study aims to determine critical feedback that should be considered when enrolling for the new qualification (B Eng Tech degree). The interview explores the rich possibilities for learning about our present and future, but only if we probe deeply through 
retrospection on the WIL programme, we should be able to explore learning opportunities so that we can improve our present qualification.

\section{LITERATURE REVIEW}

The employability of engineering graduate students; experiential learning in the engineering programme and developing communication between employers and the institutions is explored. The employability of engineering graduate students is the first aspect discussed since it is an important criterion for the success of the NDCE qualification. Other features to be discussed are: experiential learning theory; developing communication between employers and the institutions; and disadvantages of not having a WIL in an academic programme. These aspects are discussed in this literature review.

\section{The employability of engineering graduate students}

Numerous studies (Paul 2015; Zainuddin et al. 2019; Chan and Fong 2018) have found that there are particular skills that employers expect from graduates which they use to assess the employability of a graduate student. The crucial skills discussed by various authors are the following:

- $\quad$ Communication (Paul 2015; Zainuddin et al. 2019; Chan and Fong 2018);

- Professionalism (Boni-Aristizabal and Calabuig-Tormo 2016; Berjano, Sales-Nebot, and Lozano-Nieto 2013);

- $\quad$ Problem solving (Maurer and Mawdsley 2014; Chan and Fong 2018);

- $\quad$ Time management (Maurer and Mawdsley 2014, Chan and Fong 2018); and

- $\quad$ Ability to work in a team (Maurer and Mawdsley 2014; Chan and Fong 2018).

Chhinzer and Russo $(2018,104)$, in a study on "Employer Perceptions of Graduate Student Employability" confirm this by proving that professional maturity, soft skills, problem-solving, continuous learning and academic achievement positively influence an employer's perception of a graduate student. According to the study, "employers consider generic skills (time management, working in a team, attention to detail), general mental ability, subject-specific knowledge, willingness to work, attitudes and behaviors, and responsiveness to feedback when assessing employability of graduate students" (Chhinzer and Russo 2018, 107). To emphasise this, Espey $(2010,31)$ stresses that the ability to work with others is a highly valuable skill to employers, thus it is crucial to develop the skill during academic years through group work or 
team projects, prior to being exposed to the work environment (Espey 2010, 31).

It is also understood that a better academic programme for engineers is one that includes practical work experience at the early stages of the academic undergraduate programme. Paul $(2015,47)$ emphasises the crucial need to encourage undergraduate civil and environmental engineering students to gain employment skills and training right from the start of their studies (Paul 2015, 47). According to Paul, this experience increases overall employability, confidence level in networking with the industry and within the workplace, which would increase the chances of success in finding employment after finishing their studies (Paul 2015, 47). In the study, findings showed that "the virtual training approach may prove a cost-effective way of letting students gain an insight into the workplace whilst improving their employability skills during a very early stage of their studies" (Paul 2015, 47).

To prove this hypothesis, Kwan $(2016,1016)$ explores the benefits of practical learning by assessing a course called Project-based Learning (PBL) (Kwan 2016, 1016). In this study, students were given a design project which required students to apply their prior knowledge and engineering skills acquired in subjects of various disciplines of the civil engineering programme. Students commented that the course improved their understanding of design in the industry, familiarised them with the Code of Practices, and helped them acquire practical skills in engineering, such as the use of engineering software.

At the end of the programme, students seemed to have benefited a lot from applying theory in practice, even though students complained about a heavy workload (Kwan 2016, 1016). Although students reported experiencing an increased design self-efficacy through the projectbased learning course, they also reported experiencing a decrease in mathematical self-efficacy (Marshall et al. 2018, 1). These students were concerned they might not be learning "decontextualised" science and mathematics, which could be an explanation for the decrease in mathematics efficacy (Marshall et al. 2018, 1). The employability of engineering graduate students also hinges on experiential learning theory and the prospects are discussed below.

\section{Experiential Learning Theory}

Experiential learning may be defined as "a business curriculum-related endeavor which is interactive (other than between teacher and pupil) and is characterized by variability and uncertainty" (Minton-Eversole 1991). Kolb, Boyatzis, and Mainemelis $(2001,227)$ further define Experiential Learning Theory (ELT) as a theory that "provides a holistic model of the learning process and a multilinear model of adult development, both of which are consistent with what we know about how people learn, grow, and develop" (Kolb, Boyatzis, and Mainemelis 2001, 227). This concept of "experiential learning" is used to emphasise the central 
role played by experience in the learning process (Kolb, Boyatzis, and Mainemelis 2001, 227).

Multiple studies have been done to test and/or prove the reliability of experiential learning, and McCormick et al. $(2015,136)$ state that in their study, experiential learning improved sustainable engineering self-efficacy in students (McCormick et al. 2015, 136). The findings further indicated that students who participate in different experiential learning activities develop a higher self-reported motivation to engage in sustainable engineering, which reflects on their academic rank (McCormick et al. 2015, 136).

According to Chen, Shah, and Brechtelsbauer $(2016,45)$, experiential learning encourages students to be proactive with their work, especially with the assistance from supervisors and lecturers (Chen, Shah, and Brechtelsbauer 2016, 45). In a study by Sextos (2014, 18), paperless/or experiential learning proved to increase student productivity and engagement (Sextos 2014, 18). Experiential learning advances one's ability to apply theory to actual work (Yardley, Teunissen, and Dornan 2012, 102). During this phase, the student's development should be monitored closely, hence the communication between the employers and the institution needs to be maintained for the benefit of the student. The prospects are discussed below:

\section{Developing communication between employers and the institutions}

Although acquiring a college/or university qualification may seem enough for employers to give graduate students employment opportunities, university curriculum committees seem to be concerned about the selection and transference of appropriate skills and attributes for students to succeed in the industry (Newson and Delatte 2011, 1016). This suggests that there may be a gap between engineering academic programmes and actual work, which then would mean that students would not use the material learnt at a Higher Education Institutions in the workplace, and would then require further training by employers, which would then affect them financially.

To try and close this potential gap, Higher Education Institutions (HEI) need to develop and maintain communication with employers, as they are the ones who validate the applicability of the academic curriculum in actual practice (Rodman, Biloslavo, and Bratoz 2013, 72). Alpay and Jones $(2012,609)$ emphasise that amongst other HEI concerns, the most common ones are: the need to improve faculty motivation towards teaching to broaden the workplace skills of students, to widen employer engagement in teaching and to raise the relevance and value of scholarly teaching in the discipline of engineering education (Alpay and Jones 2012, 609). So far, the literature has shed light on various aspects of WIL. To show the importance of WIL, the study explores the disadvantages of not having WIL in the programme and this is discussed 
below.

\section{Disadvantages of not having WIL in an academic programme}

In order to understand the disadvantages of not having WIL in an academic programme, one needs to explore the advantages/benefits of a work-integrated learning programme to begin with According to Agwa-Ejon and Pradhan (2017), WIL refers to "an attempt to explore an academic avenue which employs an educational approach that could enable better alignment of academic and work place practices for the mutual benefit of both the students and their employers" (Agwa-Ejon and Pradhan 2017). In this definition, Agwa-Ejon and Pradhan highlight and emphasise the benefits received by both students and employers from the WIL. Finders University (2018) further highlights some of these benefits, as shown in Table 1.

Table 1: Benefits of Work Integrated Learning

\begin{tabular}{|l|l|l|}
\hline \multicolumn{1}{|c|}{ Students } & \multicolumn{1}{c|}{ Academics/ Institution } & \multicolumn{1}{c|}{ Employers } \\
\hline $\begin{array}{l}\text { Working in an environment in which } \\
\text { to put theory into practice }\end{array}$ & $\begin{array}{l}\text { The ability to integrate student } \\
\text { learning experiences into curriculum } \\
\text { development }\end{array}$ & A dose of new ideas \\
\hline $\begin{array}{l}\text { Developing an awareness of work- } \\
\text { place culture and expectations }\end{array}$ & $\begin{array}{l}\text { Create WIL opportunities for their } \\
\text { undergraduates }\end{array}$ & $\begin{array}{l}\text { Having a dedicated resource to } \\
\text { complete specific tasks or projects }\end{array}$ \\
\hline $\begin{array}{l}\text { Developing "soft" skills such as } \\
\text { communication, team work, email } \\
\text { and report-writing skills, punctuality } \\
\text { and attendance, leadership and } \\
\text { career development }\end{array}$ & $\begin{array}{l}\text { Using links to encourage employers } \\
\text { to participate on-course validation } \\
\text { panels in the development of } \\
\text { subject areas, present guest } \\
\text { lectures or participate in seminars }\end{array}$ & $\begin{array}{l}\text { The opportunity to give a potential } \\
\text { recruit a trial without obligation }\end{array}$ \\
\hline $\begin{array}{l}\text { Having an opportunity to develop a } \\
\text { practical appreciation of your } \\
\text { chosen profession }\end{array}$ & $\begin{array}{l}\text { Establishing links with a wider range } \\
\text { of employers }\end{array}$ & $\begin{array}{l}\text { Using students' reflection on work } \\
\text { experience as a recruitment } \\
\text { criterion }\end{array}$ \\
\hline $\begin{array}{l}\text { Developing an appreciation of the } \\
\text { fluidity of a rapidly changing world } \\
\text { of work }\end{array}$ & $\begin{array}{l}\text { Identifying new and innovative } \\
\text { research opportunities linked to } \\
\text { practical application }\end{array}$ & $\begin{array}{l}\text { Developing links with higher } \\
\text { education institutions and } \\
\text { informing teaching practices and } \\
\text { methodologies }\end{array}$ \\
\hline $\begin{array}{l}\text { Short-term financial benefits - some } \\
\text { students are able to earn whilst } \\
\text { studying }\end{array}$ & $\begin{array}{l}\text { The institution giving academic staff } \\
\text { the time and resources to interact } \\
\text { with the relevant industrial, } \\
\text { commercial or public sector } \\
\text { employers to enable them to } \\
\text { increase their contacts and } \\
\text { capitalize on their knowledge of the } \\
\text { field }\end{array}$ & $\begin{array}{l}\text { Staff development opportunities } \\
\text { that arise from employees } \\
\text { mentoring students }\end{array}$ \\
\hline
\end{tabular}

(Flinders University 2018, 1)

The aim of WIL experiences is to develop relevant competences that heighten employability (Fleming et al. 2009, 189), thus the inability to provide such an opportunity limits the students from acquiring skills that should lead to them being employable. The disadvantages of not having a WIL in these programmes are: firstly, the programme deprives students of the opportunity to experience a work environment prior to graduation, in order to acquire skills that competitive employees need to have, such as the ability to view actions, problems, solutions 
and consequences in a broader context comprising actual scientific, technical, economic, legal, social or cultural aspects (Staniškis and Katiliūte 2016, 13). Secondly, the institution misses the opportunity to create connectivity between the course/curriculum and the industry (Lozano and Lozano 2014, 136). Thirdly, experiential learning is said to enhance professional identity, which is defined as "the concept which describes how we perceive ourselves within our occupational context and how we communicate this to others" (Neary 2014). Trede (2012) stresses that through the experience of participating in professional roles, students are presented with an opportunity for transformative learning that shapes professional identity development and a sense of professionalism (Trede 2012, 160). Professionalism informs decision-making and judgment-based practice, which is informed by professional identity (Trede 2012, 160).

\section{METHOD}

This study is exploratory in nature, as the researcher generated a hypothesis from the data already collected. Primarily, this is a qualitative research study, which aims to explore meaning, purpose, and/or reality (Zubin and Jane 2015, 226). The quantitative portion is only used to better inform the direction of exploration, conclusion and recommendation. This method (qualitative research) is used when the study's objective is to discover and understand the experiences, perspectives and thoughts of participants. When collecting qualitative data, the participants respond to open-ended questions, which in this case would be the open request for employers and students to comment on their experiences without any limitations. Data collected were then presented and analysed using the thematic analysis method, which may be defined as a categorising strategy for qualitative data. Thematic analysis helps the researcher move the analysis from a broad reading of the data towards discovering patterns and developing themes.

The results will be presented in the following manner: students' feedback report encompassing, structures, transport, water, construction, other fields (where students were doing subjects that do not entirely belong to a specific engineering discipline), and all relevant studies (where students were involved in different engineering fields).

The students' feedback report will be followed by the employers' feedback report encompassing: structures, transport, water, construction, other fields (students who were studying subjects that do not entirely belong to a specific engineering discipline), all relevant studies (where students were doing different subjects from different engineering fields), students without matched studies (where students did not specify their theoretical background), and general. 


\section{STUDENTS' FEEDBACK REPORT}

\section{Introduction}

This report presents comments made by DUT students from five different fields of Engineering Studies post their in-service training. The five engineering fields of study are: Structural Engineering, Transport Engineering, Water Engineering, Construction, other, and all relevant studies. The field labeled as "Other" includes: Drawing I; Drawing II; Computer Skills I; Surveying I - Module 1; Surveying I - Module 2; Surveying (Civil) II - Module 1; Surveying (Civil) II - Module 2; Mathematics I; Mathematics II; and Communication Skills 1A. The field labeled as "All relevant studies" involves a combination of modules from the four engineering fields already mentioned. Out of the 593 students interviewed, six (6) had been duplicated and 16 did not specify their theoretical background. For some of the students, their theoretical background was picked up from their comments and the employers' feedback. The results are presented in a thematic format, where the themes used are the fields of studies mentioned above.

\section{Structures}

Out of 15 Structures students, six (6) had difficulty adapting to the new work environment, where they either struggled with using new work equipment, or were unable to handle the workload as a whole. Two (2) students reported having difficulty applying theory at work. One (1) of the Structures students needed more experience and six (6) did not comment perhaps as a way of refusing to answer a question, as presented in Figure 1.

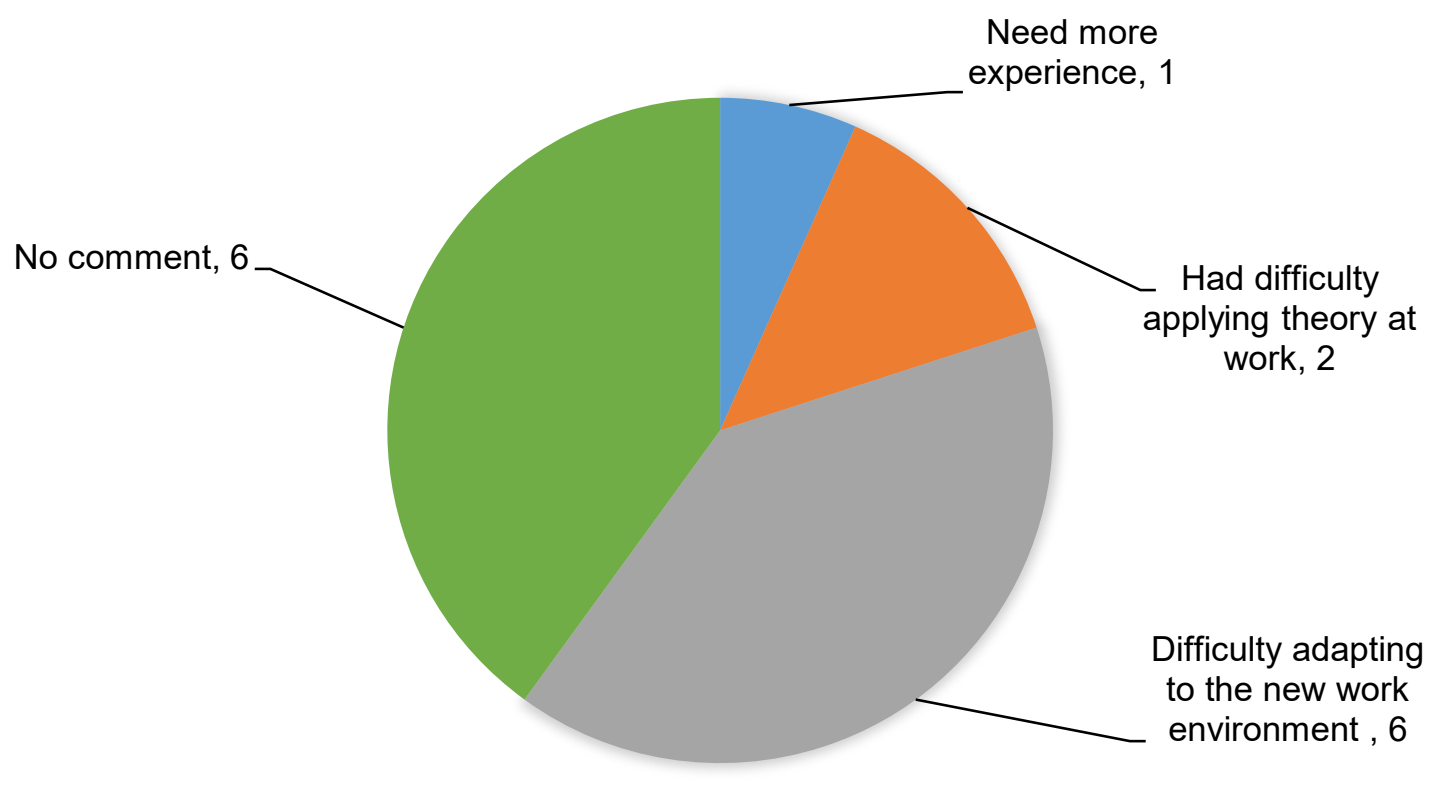

Figure 1: Comments by Structures Students 


\section{Transport}

Out of 14 Transport Engineering students, three (3) had difficulties adapting to the new work environment, which encompassed the use of new software, and the new responsibilities the students had to take on; two (2) students had challenges with supervision at work, where the people they had to give instruction to undermined them, due to the age difference; one student had difficulty applying theory at work; one student experienced challenges with communication; one student faced issues of unsafe working conditions on site, and six (6) did not comment perhaps as a way of refusing to answer a question. Figure 2 presents these findings.

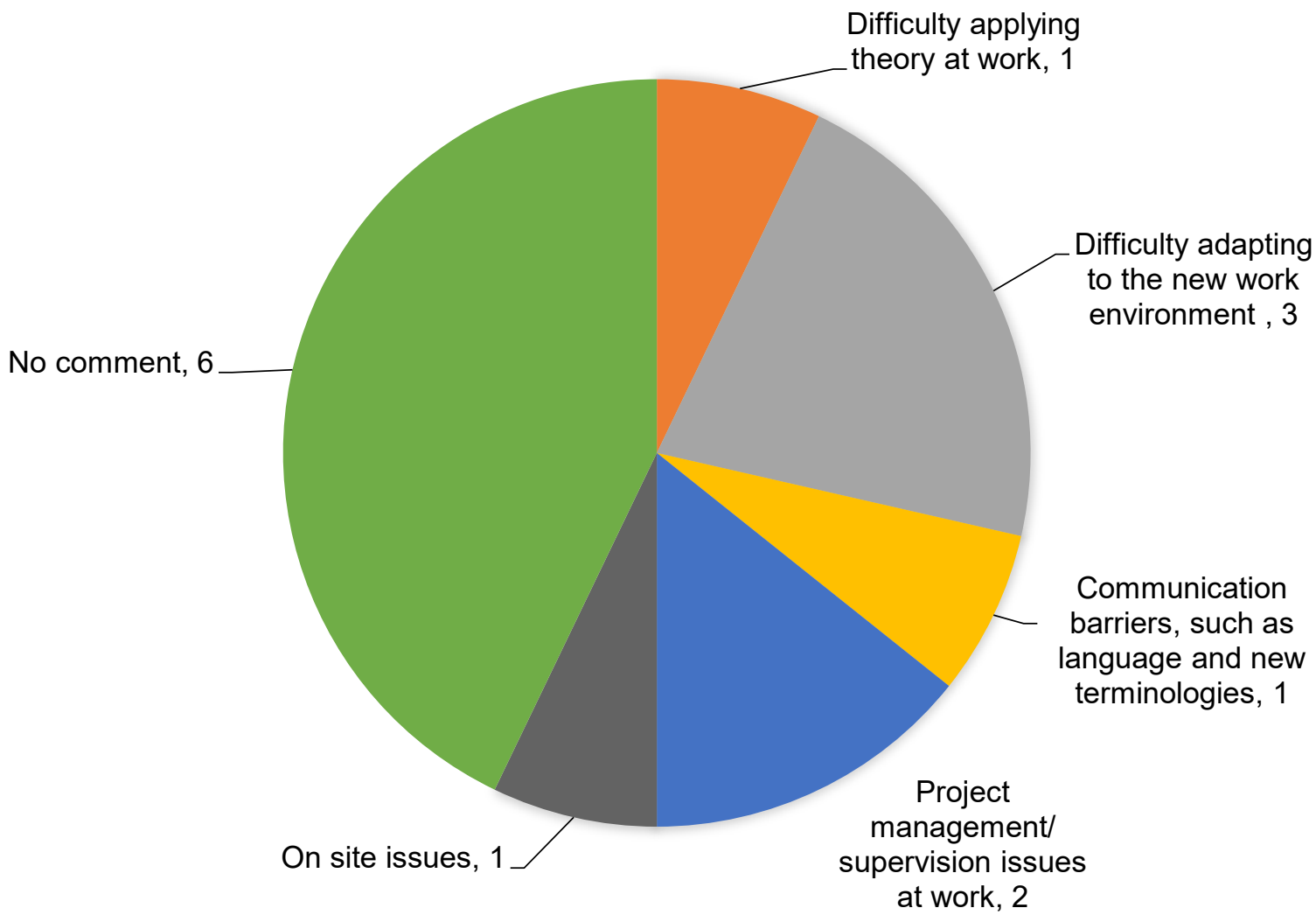

Figure 2: Comments by Transport Students

\section{Water}

Out of 23 students doing Water Engineering, four (4) had difficulty adapting to the new work environment, from being introduced to new software to being overwhelmed by the workload itself; two (2) students had supervision issues where labour did not obey them because they were students; two (2) students experienced conflicts with locals on site; another two (2) students faced safety issues on site; one (1) requested more exposure to technical civil work, such as construction; one (1) had difficulty applying theory at work; one (1) had issues 
communicating with different communities; one (1) student reported having had a pleasant experience, while nine (9) students did not comment on their experience perhaps as a way of refusing to answer a question, as presented in Figure 3.

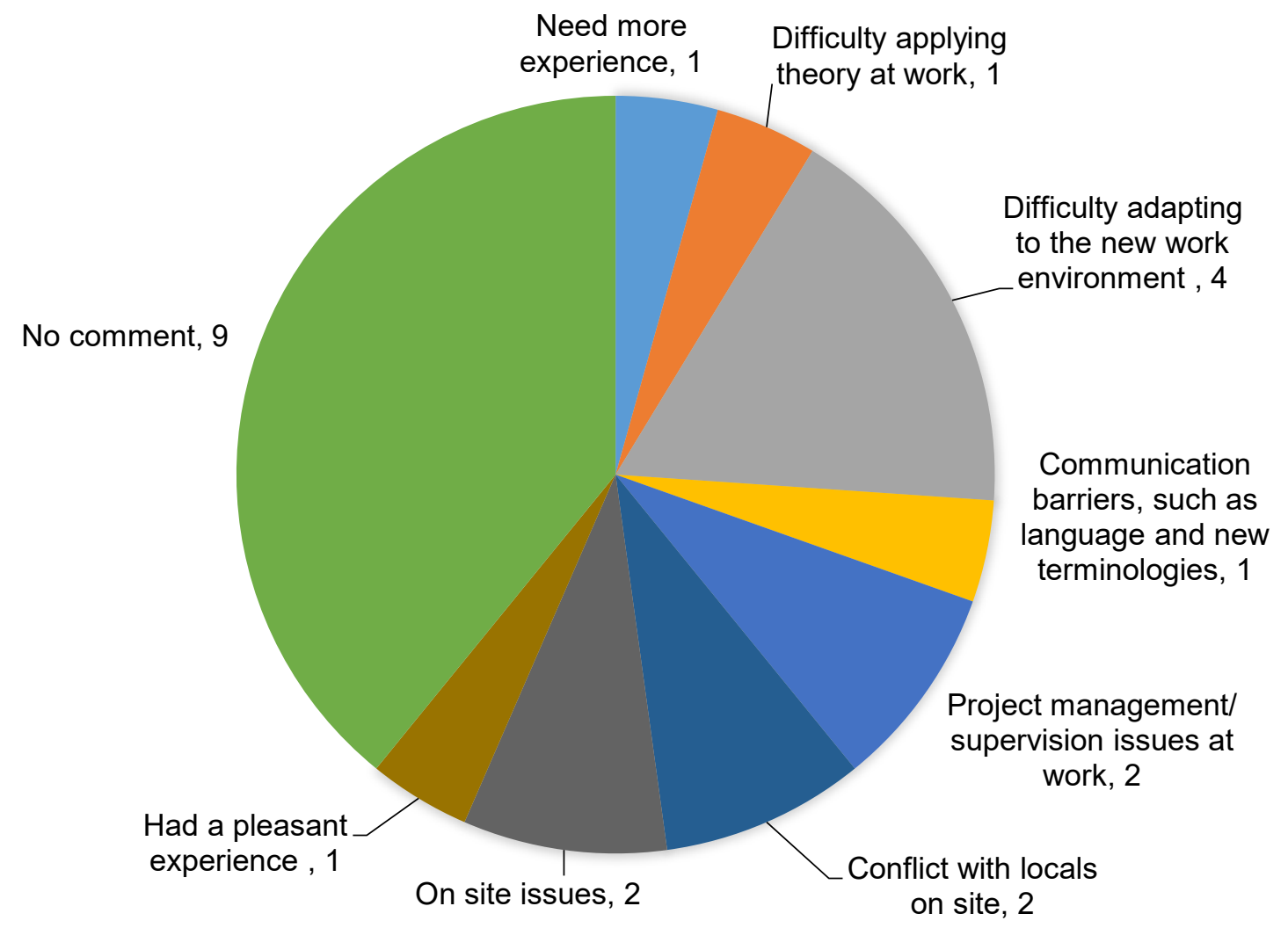

Figure 3: Comments by Water Engineering Students

\section{Construction}

Out of 90 Construction students, 11 reported experiencing issues with supervision at work, such as instructing more experienced or older people, challenges with sexist co-workers, and difficulties communicating with the contractors; 21 of the 90 students had difficulty adapting to the work environment state-of-the-art equipment, being exposed to new software to work with, the workload as a whole, and changes within the work environment itself; four (4) students experienced safety issues on site; 14 reported an unpleasant attitude received from both labour and staff, due to the age difference or sexism in the workplace; two (2) students requested more work exposure/experience; one (1) had difficulty applying theory at work; and three (3) others faced issues such as communication barriers and conflict with locals on site. One (1) student was not pleased by the experience; and 31 students did not comment on their experience perhaps as a way of refusing to answer a question. Two (2) students reported having personal challenges, as shown in Figure 4. 


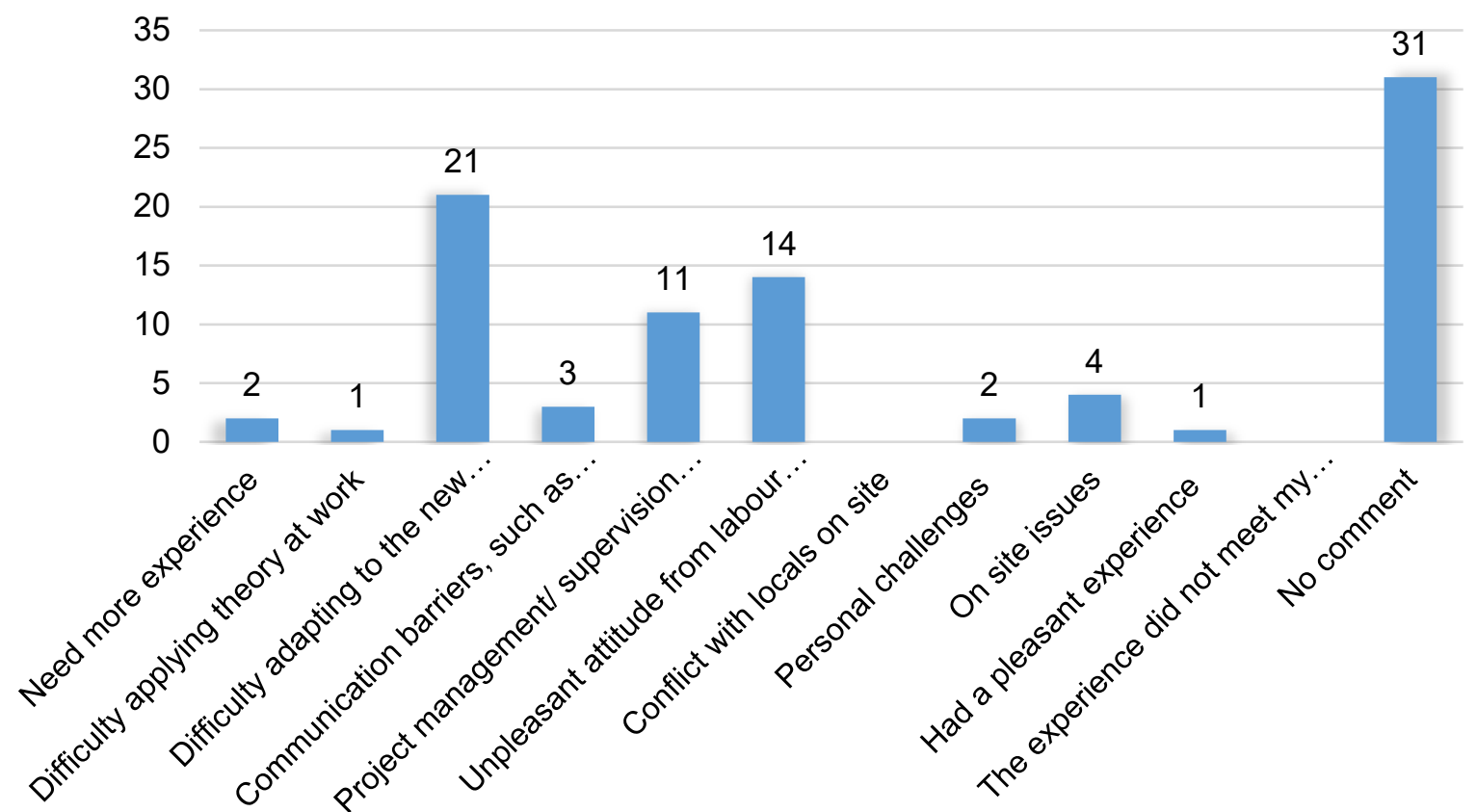

Figure 4: Comments by Construction Students

\section{Other}

In the category of "Other", where students were doing subjects that do not entirely belong to a specific engineering programme, there were 10 students. Of the 10, six (6) reported having a hard time adapting to the work environment; One (1) student requested more work exposure; two (2) students experienced supervision issues, and one (1) did not comment on the experience perhaps as a way of refusing to answer a question, as shown in Figure 5.

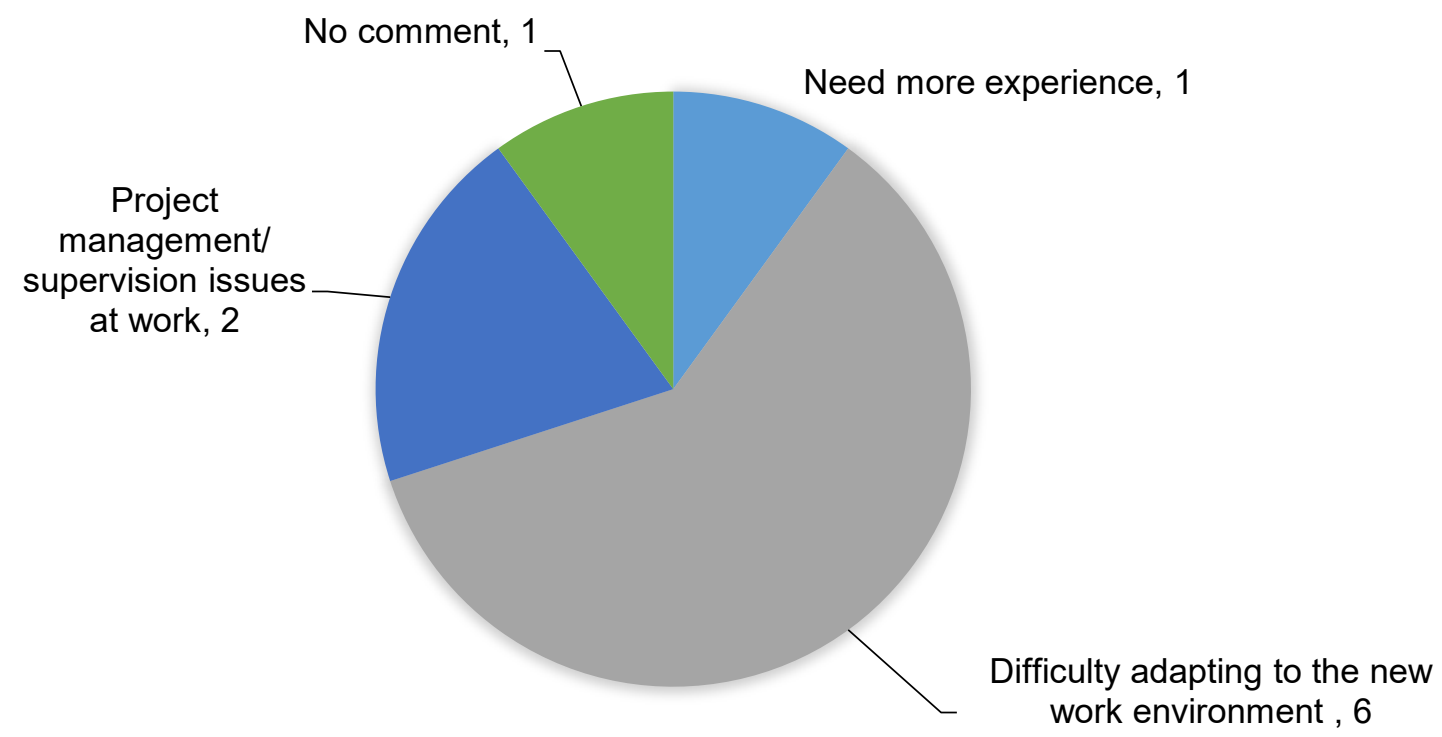

Figure 5: Comments by students doing other studies 


\section{All relevant studies}

In the category where students were involved in different engineering fields, there were 425 students. Out of the 425, 114 students reported having a difficult time adapting to the work environment and state of the art equipment; 23 had issues with supervision, where more experienced labour undermined the students due to their age, experience and sex; 50 faced unpleasant attitudes from both staff and labour; 22 reported having communication barriers, experiencing language barriers with labour and the community, and difficulties understanding engineering terminology on site; 13 students had difficulty applying theory at work; 11 experienced issues on site, such as safety issues, equipment not calibrated, logistical issues, etc.; three (3) requested more work exposure; four (4) said they had a pleasant experience; three (3) students faced personal challenges, such as the distance of the workplace from their accommodation, and tuition-related issues that affected their progress at work, and two (2) students experienced conflict on site with locals. Two (2) students said that the experience did not meet their expectations; and 178 students did not comment on their experience perhaps as a way of refusing to answer a question, as Figure 6 presents the findings.

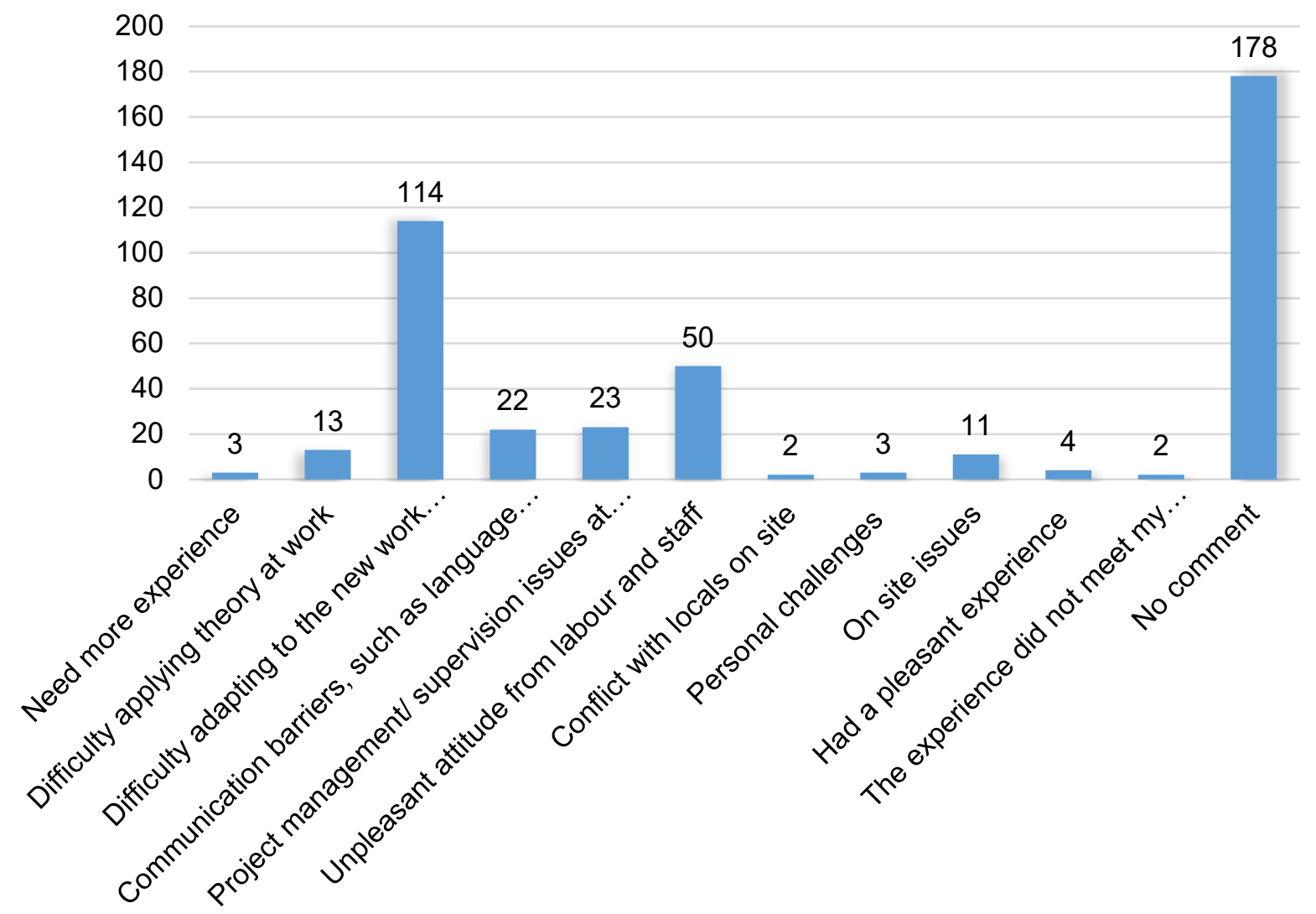

Figure 6: Comments by students studying all relevant subjects 


\section{EMPLOYER FEEDBACK REPORT}

\section{Introduction}

This report presents comments made by employers or in-service training providers for DUT students from six different fields of engineering studies, namely: Structures, Transport, Water, Construction, Other, and all relevant studies. The results are presented in a thematic format, where the themes used are the fields of studies mentioned above.

\section{Structures}

Out of 26 comments by employers on 15 Structures students, six (6) of the students were advised to get more practical experience, three (3) were advised to get more academic exposure, two (2) students were reported being shy and not confident enough, two (2) students had communication/ people skills issues, one (1) was advised to improve their project management skills, one (1) had to improve time management, and 11 students were given general comments (with respect to this study have no academic value), as presented in Figure 7.

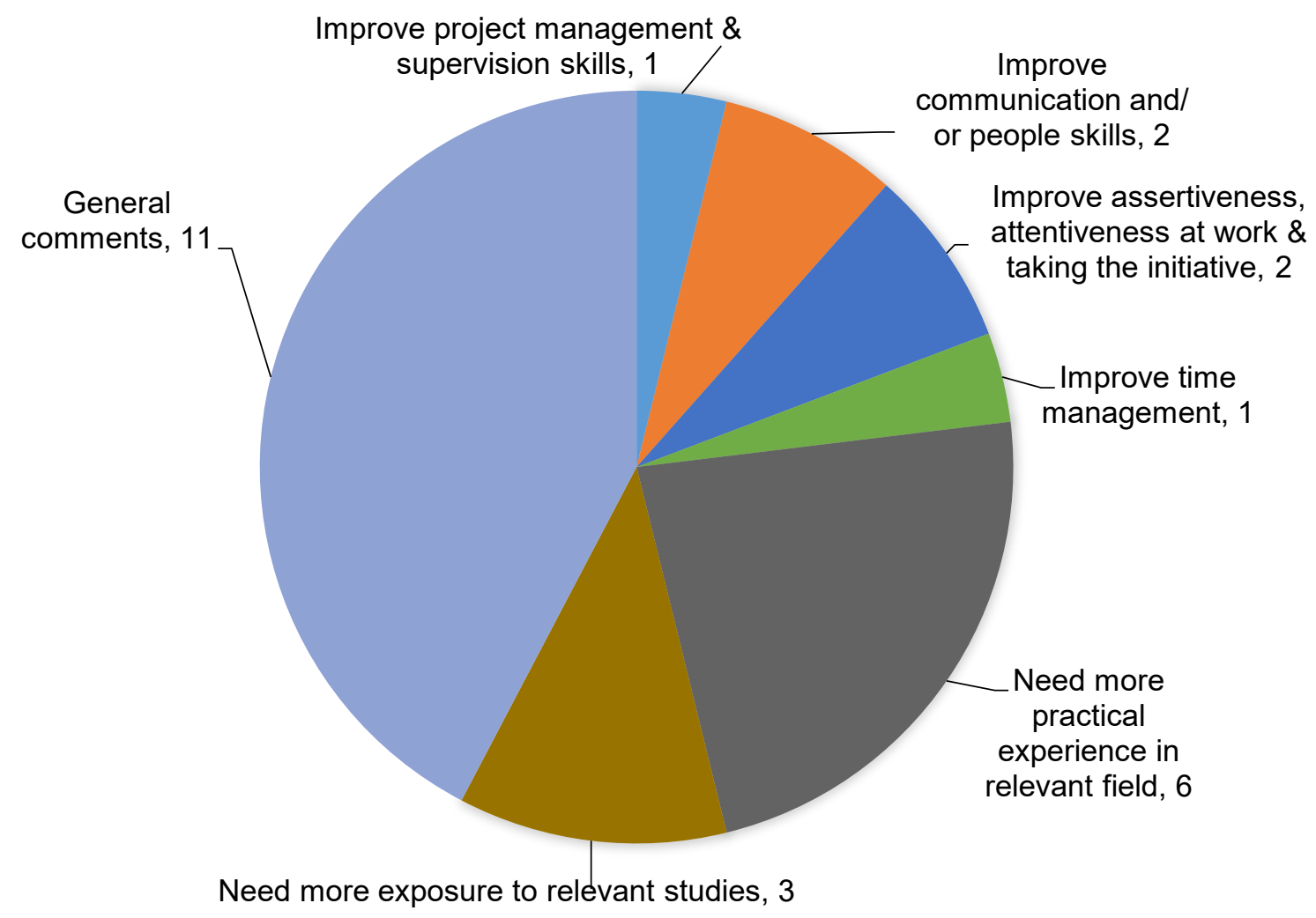

Figure 7: Comments by employers on Structures students

\section{Transport}

Out of 24 comments by employers on 14 Transport Engineering students, the employers' 
comments proposed that five (5) students needed more practical experience and five (5) needed to get more exposure to their studies. Employers expressed being concerned by the assertiveness of three (3) students, while two (2) students were said to be lacking communication skills. Nine (9) students received general comments (with respect to this study have no academic value), as presented in Figure 8.

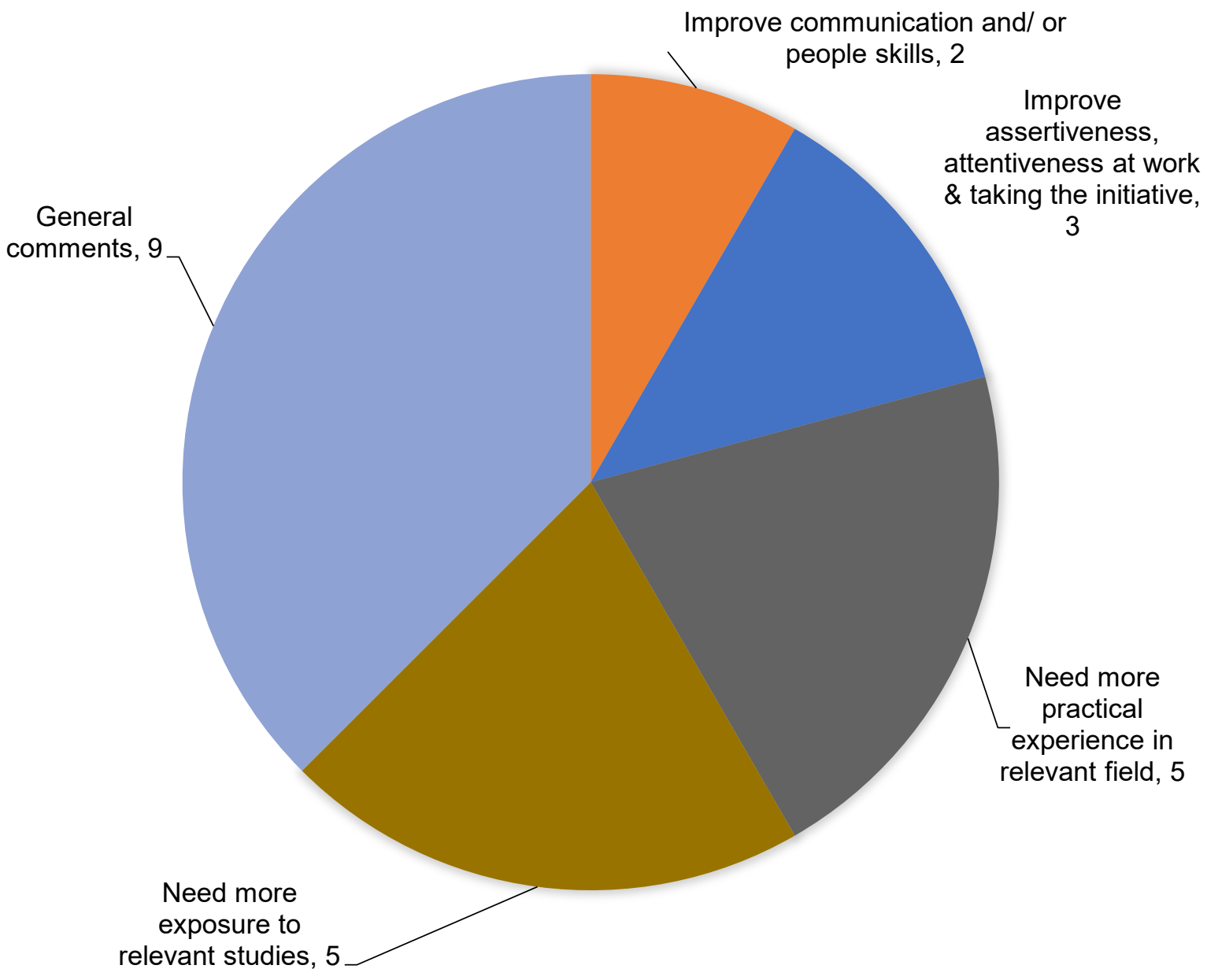

Figure 8: Comments by employers on Structures students

\section{Water}

Out of 38 comments by employers on 23 students studying Water Engineering, employers recommended eight (8) students to get more academic experience, six (6) students were requested to get more practical experience, while five (5) students were asked to improve their assertiveness and attentiveness to their work; 18 general comments were also given. One commenter suggested that students should be willing to work, as presented in Figure 9. 


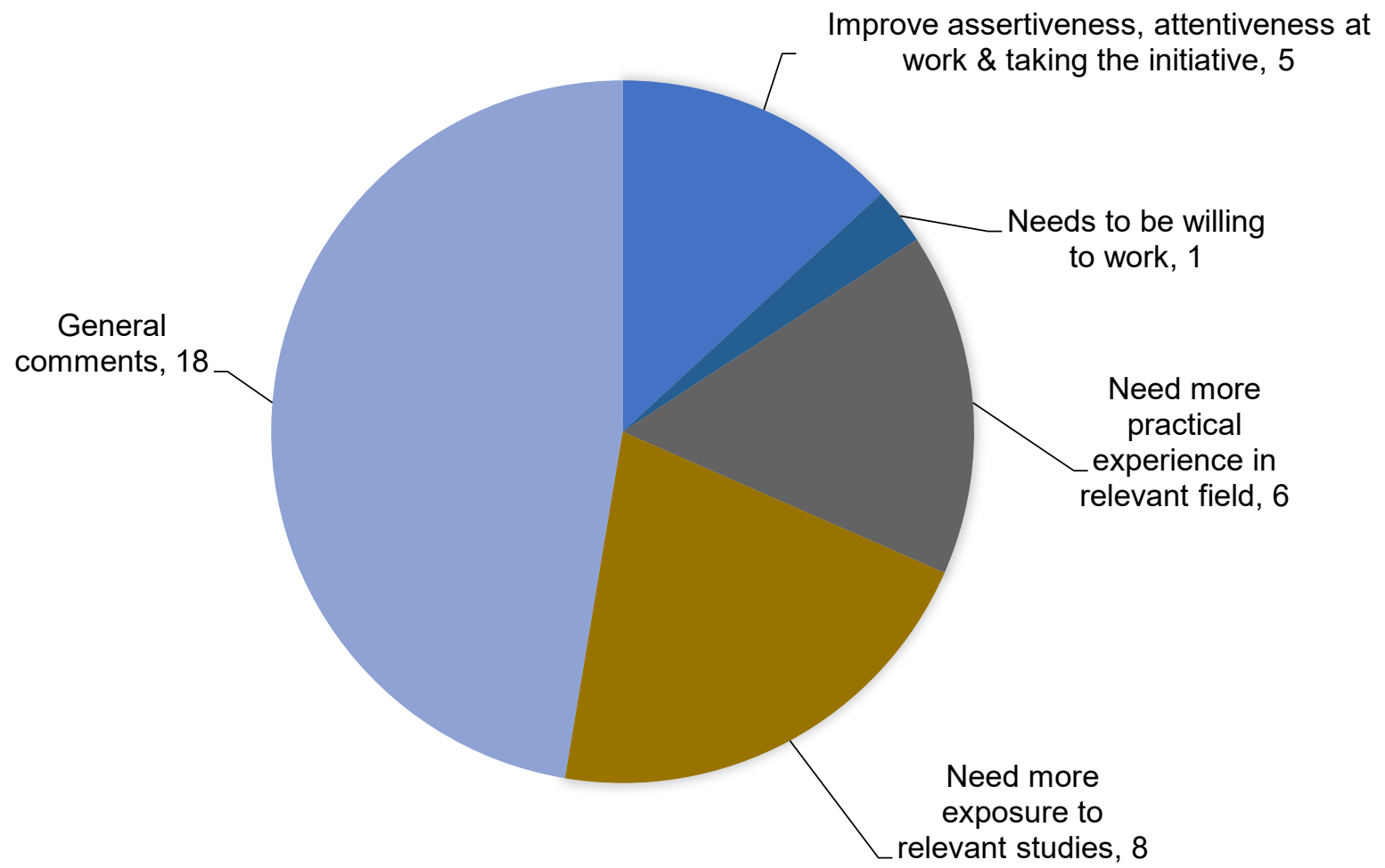

Figure 9: Comments by employers on Water Engineering students

\section{Construction}

Out of 190 comments by employers on 90 Construction students, employers proposed that 38 students get more academic exposure, while 25 students were advised to get more practical experience. Employers raised a concern that 38 students needed to improve their assertiveness and attentiveness to their work. Ten students were advised to improve their communication skills, six (6) were advised to improve their project management and supervision skills, while four (4) students were reported having issues with applying theory or their knowledge on the ground/or in practice, one (1) student was advised to improve their time management. The employers also gave 68 general comments, as shown in Figure 10.

\section{Other}

The category of "Other" represents students who were studying subjects that do not entirely belong to a specific engineering programme. In this category, employers made 18 comments on 10 students. Out of the 18 comments, six (6) students were advised to get more academic exposure in their studies, two (2) were recommended to get more practical experience, two (2) students were reported having communication issues, while two (2) were advised to improve their assertiveness and attentiveness at work. Six (6) general comments were given to some of the students, as shown in Figure 11. 


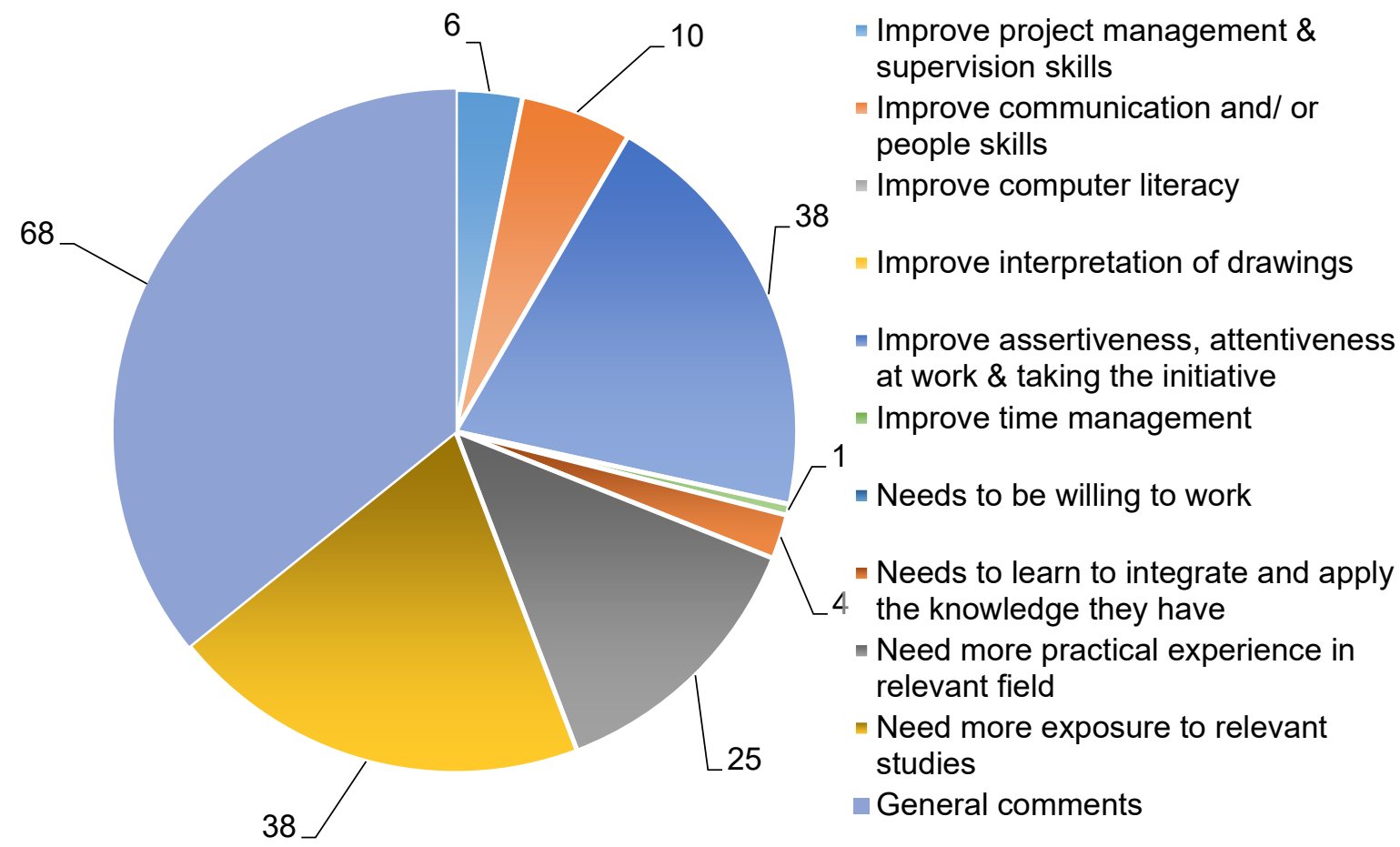

Figure 10: Comments by Employers on Construction students

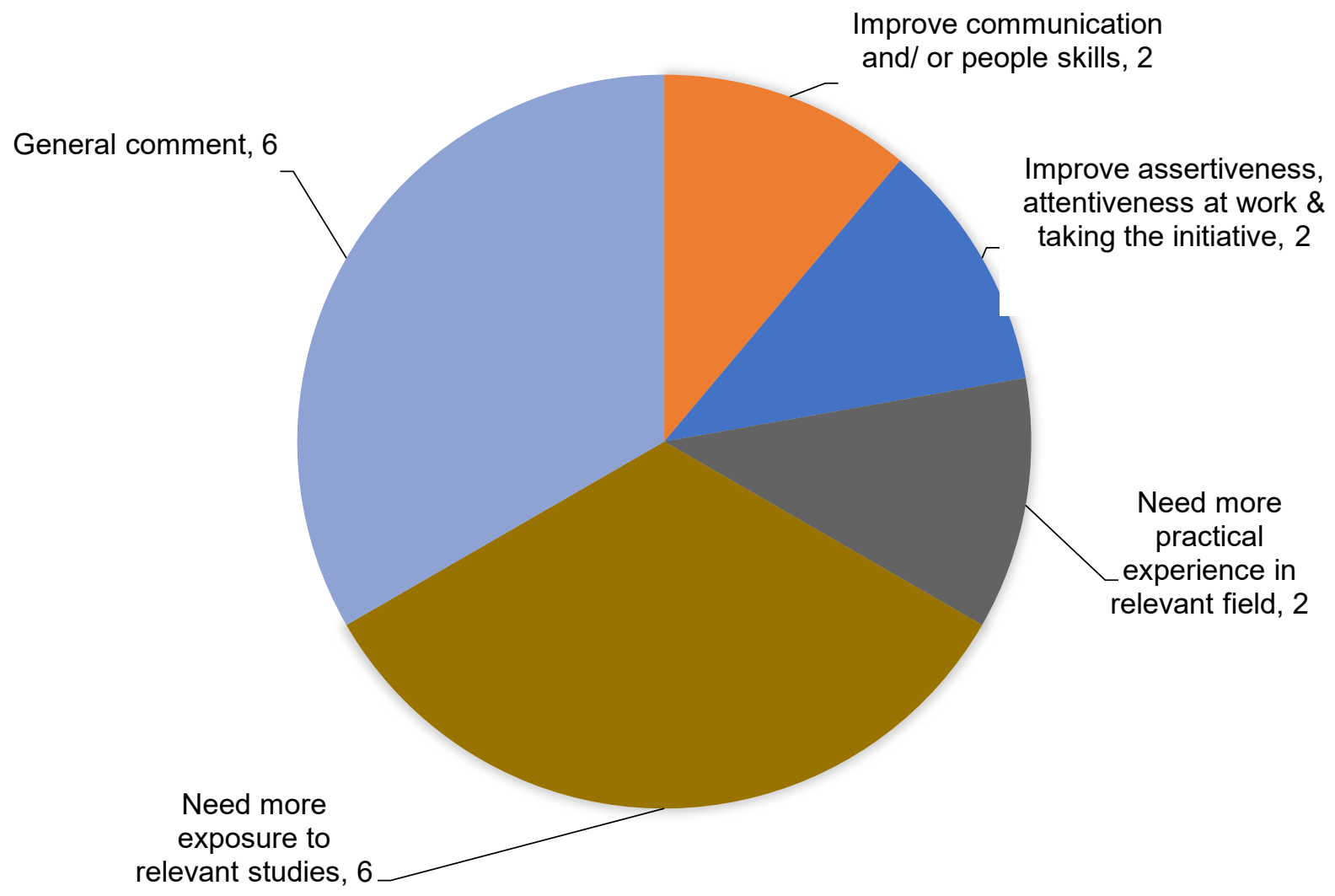

Figure 11: Comments by employers on students doing other studies 


\section{All relevant studies}

In the category where students were doing different subjects from different engineering fields, there were 605 comments by employers on 425 students. Out of the 425 students, 129 were advised to get more exposure to relevant studies, 111 were recommended to get more practical experience in relevant fields, 102 were requested to improve their assertiveness and attentiveness at work, 29 were asked to improve their communication skills, 23 were reported being unable to integrate and apply the knowledge they have, while 11 students were recommended to improve their project management and supervision skills. Nine (9) students were reported having problems with time management, one (1) was showing signs of not being willing to work, and 190 students were given general comments (with respect to this study have no academic value). Figure 12 presents these findings.

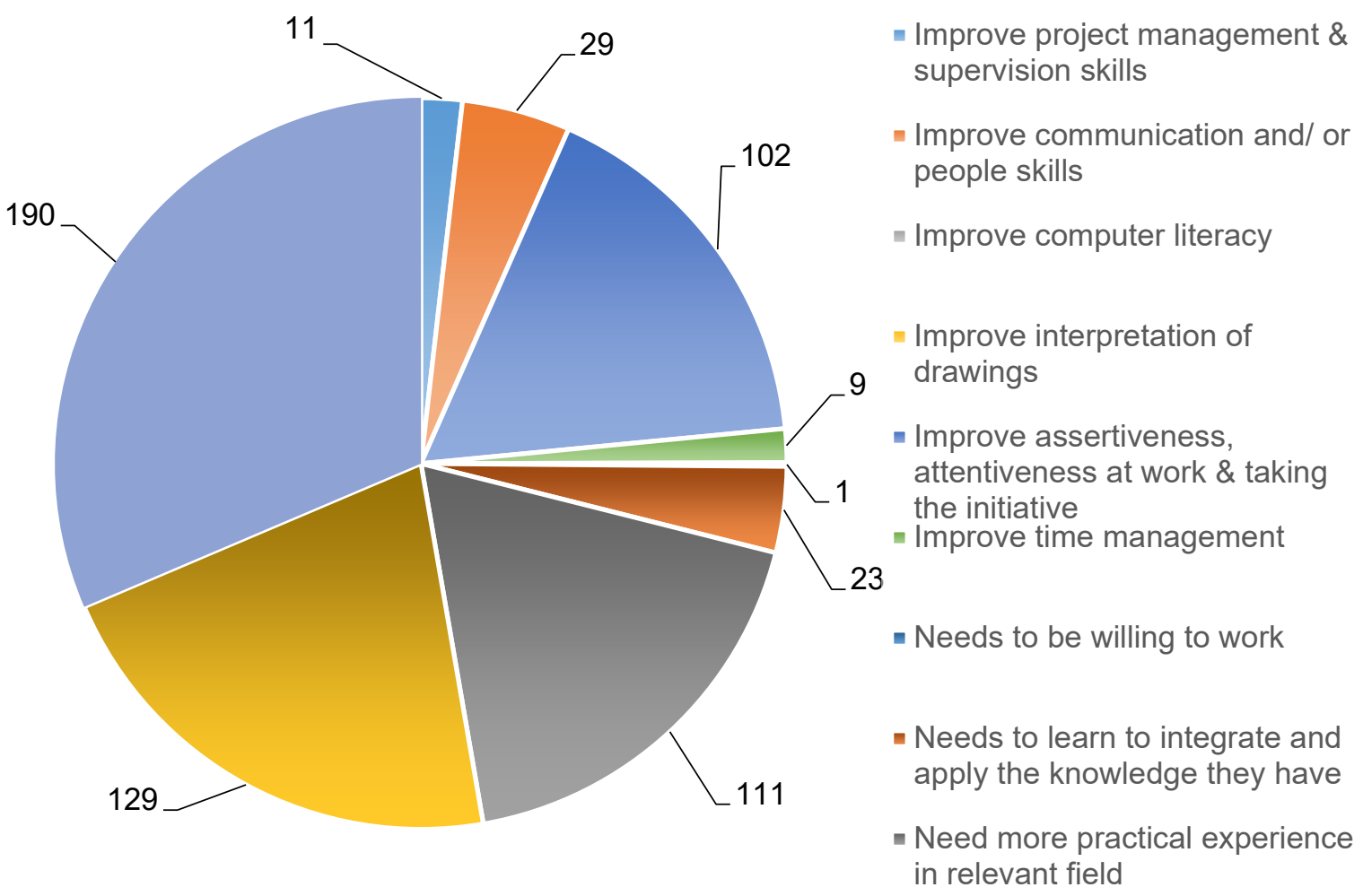

Figure 12: Comments by employers on Students studying all relevant subjects

\section{Students without matched studies}

In the category where students did not specify their theoretical background, there were 17 comments by employers. Out of the 17, employers recommended four (4) students to improve communication/people skills, four (4) were advised to get more academic exposure, three (3) were recommended to improve their management and supervision skills, three (3) were urged 
to improve their assertiveness, and one was advised to get more practical experience. There were two general comments received. Figure 13 presents these findings.

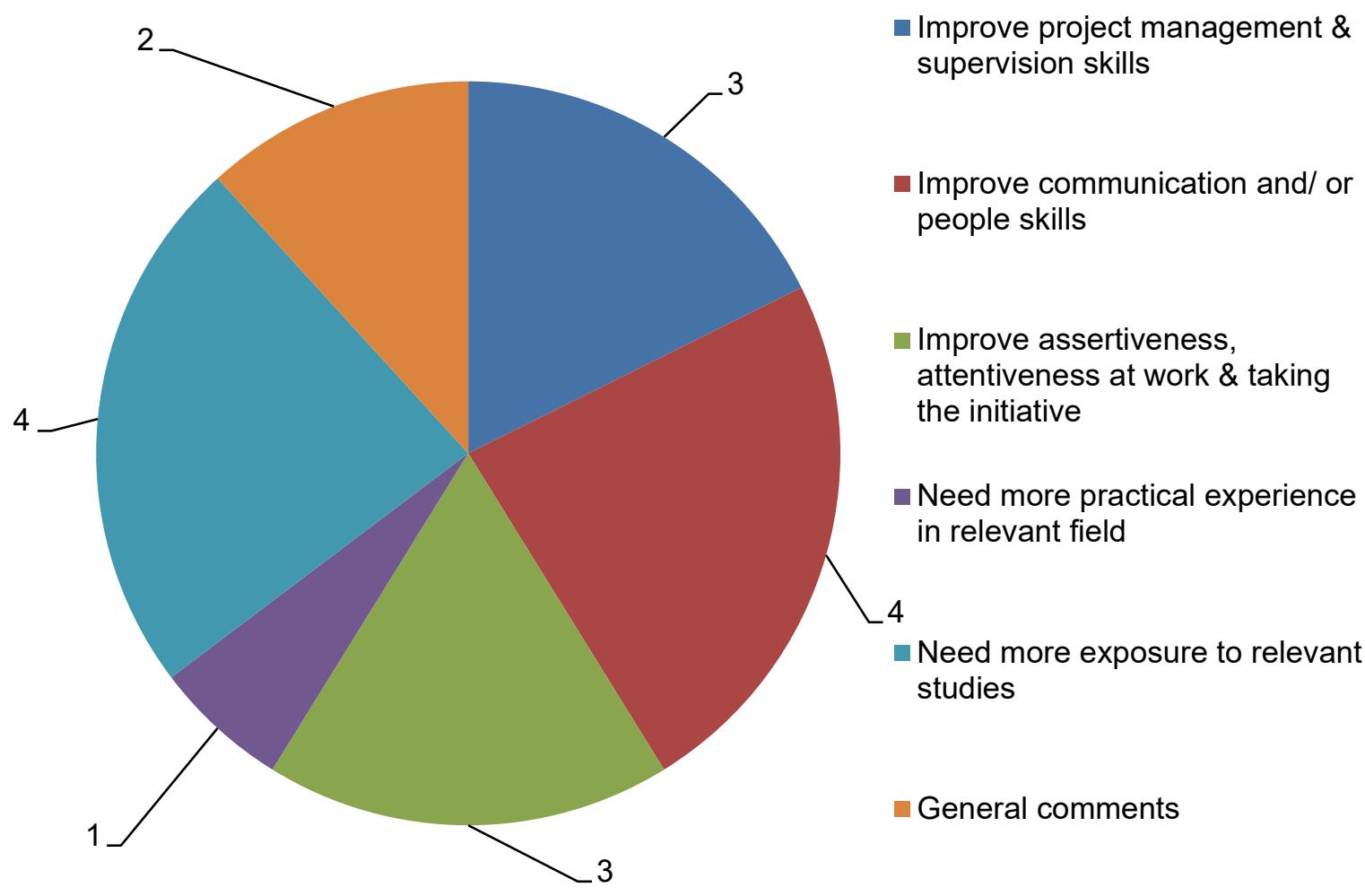

Figure 13: Comments by employers on students with no specified theoretical background

Out of 301 general comments, 205 comments involved praise or good opinions of the institution and/or students' abilities, 55 were requests for better communication with the industry and with students while doing their in-service training. However, seven (7) comments expressed a concern with the disparity between academic programmes and actual work in the engineering field, and advised that the institution should try to update and align their programmes with what is happening on the ground. Twenty (20) comments proposed that DUT should introduce an induction programme to introduce students to professionalism, while 10 comments advised that obtaining a driver's license before the in-service training would be highly beneficial to the students. Four (4) comments expressed concerns about student unrest on campus, as presented in Figure 14. 


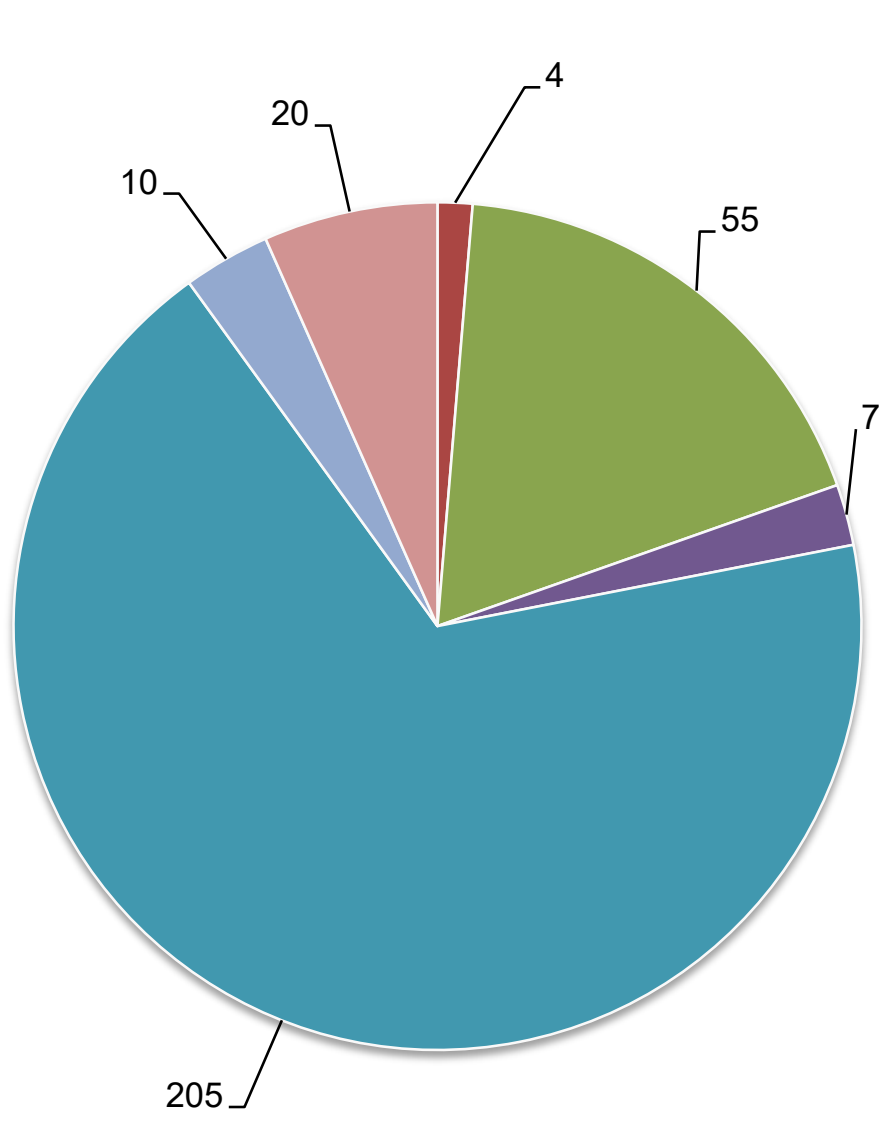

- SAICE Student chapter

- Disruptions by student unrests

- Guidelines for and communication with employers and students w.r.t Inservice training. Visiting Students on site

- Disparity between academic training and practical work

- Employer has good opinion of the institution and students' abilities

- Civil industries responsibilities to students

A driver's license would be beneficial for all students

- Introduce an induction program to introduce students to professionalism

Figure 14: General comments by employers

\section{CONCLUSION}

The article revisited the records of structured interviews for the phased out National Diploma in Civil Engineering (NDCE) Work Integrated Learning (WIL) section - employer and student experience. The aim of the study was to synthesise a large quantity of unorganised collected data and information and to reformat this in a way that renders it accessible and useful. The objective was to present the data chronologically and in a state that can easily be digested by readers. In doing so, we were able to achieve the following, (1) provide factual data to inform the development of the new qualification: Bachelor of Engineering Technology Degree in Civil Engineering (B Eng Tech degree); and (2) share the outcomes with the public and the world of academia of a study concerning employer and student experience of the Durban University of Technology (DUT), Civil Engineering programme.

\section{The conclusion drawn from the employer's perspective about our students}

The employers were very happy with the quality of the students produced by DUT. However, as much as it was clear the institution had prepared the students well with the content of the work, professionalism seemed to be of major concern. It should be noted that this is a common 
concern and numerous items of literatures point to professionalism as a deficiency among students and further suggest methods to improve professionalism.

A common request from employers was that DUT needs to communicate with employers regarding their curriculum so that the employers may be aware of what to expect from students and what it is that students need to cover in their training.

Employers also recommended that the institution should expose students to practical work while doing their academic programme, and also expose students to presentations, in order to boost their confidence, communication skills, and to give them a feel of what employment will be like in the field.

The three points above suggest a relationship between appearing unprofessional and the student's lack of industry expectation and lack of presentation skills, which some employers see as being associated with lack of confidence and poor communication skills.

Perhaps it would assist all institutions of education to make it a custom to reflect on employer and student/graduate experiences and to make findings available to other institutions or to the public at decade intervals.

\section{The conclusion you can draw from the student's perspective about their employers}

Students were pleased with their in-service training, with a few concerns in a few areas. Most students were challenged by the new work environment they had entered, with an increased work load and challenging working hours.

The most common factor that made the experience more challenging for students, however, was the exposure to new technologies and equipment such as BIM and GNSS/GPS systems that students had never worked with before. This issue then emphasises the concern that the institution needs to communicate with employers in order for a synergy to exist between the two worlds of academia and in-service training.

\section{LESSONS FOR THE NEW QUALIFICATION: BACHELOR OF ENGINEERING TECHNOLOGY DEGREE IN CIVIL ENGINEERING (B ENG TECH DEGREE)}

Considering the outcomes of the study, the Durban University of Technology could produce the calibre of students who could perform equally well or better in the industry with respect to aspects laid out at the conclusion of this study despite the exclusion of WIL in the enrolled programme.

Although it was clear that the institution prepared students well with respect to the content of the work in the phased out programme, currently there is uncertainty whether or not this will 
be maintained or improved on in the enrolled qualification due to the diversity of the two qualifications (phased out and new programme). The programme should be designed in such a way that it can develop/teach professionalism skills to students.

The new qualification should have a fully functional mechanism that encourages a regular two-way communication between employers and the institution through Advisory Board meetings. This will enable both parties to be aware of the expectations of both the graduates and employers. By doing this, students will be better prepared when entering the industry and employers can anticipate the calibre of students they are getting. Creating communication as early as possible will buy the institution time to make improvements where necessary thus saving retrofitting time in a worst-case scenario.

Lecturers need to be up to date with what is happening on the ground, in order to better prepare the students for the work environment. The possibility of seconding lecturers to industry needs to be discussed at Advisory Board meetings. With this communication or connection in place, students would not face such a challenge of adapting to the work environment by learning to use new equipment they had never used before, and of spending more time on learning to use new equipment than on actual work, which would be a waste of time for both the student and the employer.

Although the new programme has no WIL, it should find sustainable mechanisms for exposing students to practical work whilst enrolled for the academic programme. This can be achieved in encouraging students to secure vacation work during winter and summer breaks.

The students should be rigorously exposed to presentations during the academic programme. As suggested by employers, this will help boost their confidence and communication skills.

The new programme should train the students on how to deal with an increased workload. This can be achieved by giving students impromptu assessments during the academic calendar with feasible submission dates. State of the art equipment should be utilised to train students.

\section{FUTURE STUDIES}

Future studies should investigate if there is any correlation between unprofessionalism (appearing unprofessional) and student's lack of what to expect in the industry. Furthermore, an investigation is needed into the relationship between unprofessionalism (appearing unprofessional) and student's lack of presentation skills, which employers appear to associate with lack of confidence and poor communication skills.

Perhaps it would assist all institutions of education to make it a custom to reflect on employer and student/graduate experiences and to make findings available to other institutions 
or to the public at decade intervals.

\section{ACKNOWLEDGEMENT}

The authors' gratitude is extended to Jeff Moys for conducting and coordinating interviews between 2017 and 2018.

\section{REFERENCES}

Agwa-Ejon, J. F. and A. Pradhan. 2017. "The impact of work integrated learning on engineering education.” In 2017 IEEE Global Engineering Education Conference (EDUCON), 1258-1265. IEEE.

Alpay, E. and M. E. Jones. 2012. "Engineering education in research-intensive universities." European Journal of Engineering Education 37(6): 609-626. doi: 10.1080/03043797.2012.736953.

Berjano, Enrique, Laura Sales-Nebot, and Albert Lozano-Nieto. 2013. "Improving professionalism in the engineering curriculum through a novel use of oral presentations." European Journal of Engineering Education 38(2): 121-130. doi: 10.1080/03043797.2012.745829.

Blom, Andreas and Hiroshi Saeki. 2011. Employability and skill set of newly graduated engineers in India: The World Bank.

Boni-Aristizabal, A. and C. Calabuig-Tormo. 2016. "Enhancing pro-public-good professionalism in technical studies." Higher Education 71(6): 791-804. doi: 10.1007/s10734-015-9916-4.

Chan, C. K. Y. and E. T. Y. Fong. 2018. "Disciplinary differences and implications for the development of generic skills: A study of engineering and business students' perceptions of generic skills." European Journal of Engineering Education 43(6): 927-949. doi: 10.1080/03043797. 2018.1462766.

Chen, W., U. Shah, and C. Brechtelsbauer. 2016. "The discovery laboratory - A student-centred experiential learning practical: Part I - Overview.” Education for Chemical Engineers 17: 44-53. doi: 10.1016/j.ece.2016.07.005.

Chhinzer, N. and A. M. Russo. 2018. "An exploration of employer perceptions of graduate student employability." Education + Training 60(1): 104-120. doi: 10.1108/ET-06-2016-0111.

Cooper, Lesley, Janice Orrell, and Margaret Bowden. 2010. Work integrated learning: A guide to effective practice: Routledge.

De Stavenga Jong, Jan A., Ronny F. A. Wierstra, and José Hermanussen. 2006. "An exploration of the relationship between academic and experiential learning approaches in vocational education." British Journal of Educational Psychology 76(1): 155-169.

Espey, M. 2010. "Valuing Teams: What Influences Student Attitudes?” NACTA Journal 54(1): 31-40.

Fleming, J., A. J. Martin, H. Hughes, and C. Zinn. 2009. "Maximizing work-integrated learning experiences through identifying graduate competencies for employability: A case study of sport studies in higher education." Asia-Pacific Journal of Cooperative Education 10(3): 189.

Flinders University. 2018. "Benefits of work-Integrated Learning." Last Modified 13 July 2018. https://staff.flinders.edu.au/learning-teaching/wil.

Jackson, Denise. 2015. "Employability skill development in work-integrated learning: Barriers and best practice." Studies in Higher Education 40(2): 350-367.

Kolb, D. A., R. E. Boyatzis, and C. Mainemelis. 2014. "Experiential Learning Theory: Previous Research and New Directions." In Perspectives on thinking, learning, and cognitive styles, 227 248. Routledge.

Kwan, C. L. 2016. "Findings from the implementation of project-based learning in civil engineering education." SHS Web of Conferences 26: 1016. doi: 10.1051/shsconf/20162601016.

Lozano, F. J. and R. Lozano. 2014. "Developing the curriculum for a new Bachelor's degree in 
Engineering for Sustainable Development." Journal of Cleaner Production 64: 136-146. doi: 10.1016/j.jclepro.2013.08.022.

Majumdar, Anshuman. 2017. "MacACM: Encouraging competitive programming via mentorship and outreach.” XRDS: Crossroads, The ACM Magazine for Students 24(1): 14-15.

Marshall, J., A. Bhasin, S. Boyles, B. David, R. James, and A. Patrick. 2018. "A project-based cornerstone course in civil engineering: Student perceptions and identity development." Advances in Engineering Education 6(3): 1-25.

Maurer, H. and J. Mawdsley. 2014. "Students' Skills, Employability and the Teaching of European Studies: challenges and opportunities." European Political Science 13(1): 32-42. doi: 10.1057/eps.2013.34.

McCormick, M., A. R. Bielefeldt, C. W. Swan, and K. G. Paterson. 2015. "Assessing students' motivation to engage in sustainable engineering." International Journal of Sustainability in Higher Education 16(2): 136-154. doi: 10.1108/IJSHE-06-2013-0054.

Minton-Eversole, T. 1991. Learning from Experience - Guide to Business Gaming and Experiential Learning, ed. James W. Gentry. Madison: Association for Talent Development.

Nair, Prashant R. 2020. "Increasing Employability of Indian Engineering Graduates through Experiential Learning Programs and Competitive Programming: Case Study." Procedia Computer Science 172: 831-837. doi: https://doi.org/10.1016/j.procs.2020.05.119.

Neary, S. 2014. "Professional Identity: What I call myself defines who I am." http://hdl.handle.net/ $10545 / 324124$.

Newson, T. A. and N. J. Delatte. 2011. "Case methods in civil engineering teaching." Canadian Journal of Civil Engineering 38(9): 1016-1030. doi: 10.1139/L11-023.

Oliver, Beverley. 2015. "Redefining graduate employability and work-integrated learning: Proposals for effective higher education in disrupted economies." Journal of Teaching and Learning for Graduate Employability 6(1): 56.

Paul, P. 2015. "Virtual Placements to Develop Employability Skills for Civil and Environmental Engineering Students." Education Sciences 5(2): 47-64. doi: 10.3390/educsci5020047.

Rodman, K., R. Biloslavo, and S. Bratoz. 2013. "Institutional quality of a higher education institution from the perspective of employers." Minerva 51(1): 71-92. doi: 10.1007/s11024-013-9219-9.

Sextos, A. G. 2014. "A paperless course on structural engineering programming: Investing in educational technology in the times of the Greek financial recession." European Journal of Engineering Education 39(1): 18-30. doi: 10.1080/03043797.2013.824413.

Smith, C., S. Ferns, and L. Russell. 2014. The impact of work integrated learning on student workreadiness. Office for Learning and Teaching, Department of Education.

Staniškis, J. K. and E. Katiliūtè. 2016. "Complex evaluation of sustainability in engineering education: Case and analysis." Journal of Cleaner Production 120: 13-20. doi: 10.1016/ j.jclepro.2015.09.086.

Trede, F. 2012. "Role of work-integrated learning in developing professionalism and professional identity." Asia-Pacific Journal of Cooperative Education 13(3): 159-167.

Winberg, Christine, Penelope Engel-Hills, James Garraway, and Cecila Jacobs. 2011. "Work-integrated Learning: Good Practice Guide." HE Monitor No. 12. Council on Higher Education (CHE).

Yardley, S., P. W. Teunissen, and T. Dornan. 2012. "Experiential learning: AMEE Guide No. 63." Medical Teacher 34(2): e102-e115. doi: 10.3109/0142159X.2012.650741.

Zainuddin, S. Z. B., S. Pillai, F. P. Dumanig, and A. Phillip. 2019. "English language and graduate employability." Education + Training 61(1): 79-93. doi: 10.1108/ET-06-2017-0089.

Zubin, A. and S. Jane. 2015. "Qualitative Research: Data Collection, Analysis, and Management." The Canadian Journal of Hospital Pharmacy 73(1): 226-231. 